\title{
MACROECONOMIC MODELLING OF A FIRM'S DEFAULT
}

\author{
Michal Řičař *
}

\section{Introduction}

Prediction of a firm's default and analysis of its main causes is one of the perspective fields in the current business. Today's economy is highly based on information. Information about suppliers and consumers can divide firms into those that will survive in the economic competition and those that have to be liquidated as a result of their unsatisfying decision-making and insufficient information.

Scoring is a tool that can provide this kind of information about customers and suppliers - a probability of default in the next 12 months. This information may prevent possible damage to a firm's stability which can come mainly from disruption of its cash flow. In this context, it is clear that scoring can provide useful information which can save a firm from "bad" customers and suppliers.

To build a good scoring model, it is necessary to have relevant data available. The key component is a good database with time series of firms' defaults and also financial and demographic data for the economy which is being analysed. A microeconomic model could be built on the basis of these data which provides a probability of default. The second important component in a scoring model is a macroeconomic environment. If we connect a macroeconomic model with a micro model, we should obtain more accurate predictions of defaults. In this article, we focus on the macro-component to reveal if there exists a connection between corporate default and macroeconomic condition in the Czech economy to predict the total number of defaults in the Czech Republic. This component is usually used by rating companies to improve their rating models.

Empirical models which link defaults with macro variables can be found in Bangia, Diebold, Kronimus (2002), Kavvathas (2001), Nickell, Perraudin, Varotto (2000), Pesaran, Schuermann, Treutler (2003), and Wilson (1997). The general conclusion of these models is consistent with our intention - the probability of default is higher in recession states. Kavvathas (2001) showed that credit risk migrates over the business cycle by using the Markov chain and the likelihood function. Nickell, Perraudin, Varotto (2000) made the same conclusion as Kavvathas (2001) by using two approaches

* University of Economics, Prague, Faculty of Informatics and Statistics (michal.ricar@vse.cz).

We gratefully acknowledge the support of this project by the research grant IGA IG403052. 
to estimate rating change probabilities. The first was simple use of frequencies, the second approach was based on probit modelling. In both cases they proved the influence of the business cycle on ratings, and also that defaults vary among countries, e.g., the volatility of ratings in Japan was lower than in the US or the UK.

For better understanding of corporate defaults, it is important to mention the commonly known five stages of corporate life cycle analysed by Miller and Friesen (1984), who concluded some very interesting results. Briefly, "the birth phase shows small, young, owner-run firms trying to establish a space for themselves through much product innovation. The growth phase is characterized by larger, rapidly growing, departmentalized organizations expanding their space in the market and evolving a more formalized organization structure. In the maturity phase, firms have stability and efficiency as their goal, their level of innovation drops, and a more bureaucratic structure is adopted. The revival phase is one of product market diversification and of the adoption of a divisionalized market-based rather than a function-based structure; high levels of innovation are maintained and emphasis is given to the use of formal controls. Finally, the decline phase shows firms that are beginning to stagnate as markets dry up and product lines become antiquated. An interesting finding was that the firms seemed to go through the five phases in a manner only roughly resembling that postulated by the literature. That is, birth led to growth which usually led to maturity, which only sometimes led to revival. Decline phases could be reached from all but the birth phase and were most often reversed by movement to the revival phase. Generally, firms tended to spend at least ten years in the growth, maturity, and revival phases. While the general thrust of the conceptual literature is vindicated regarding the nature of and differences among the stages of the life cycle, there are many ways in which organizations string these phases together throughout their histories." Miller and Friesen (1984).

Our data were based on firms in all the phases, which means that we did not differentiate whether a firm was younger or older before default occurred. This decision - to do not differentiate between firms' stages - was supported by the above mentioned article by Miller and Friesen (1984), where the authors concluded that a default can appear in any stage, thus we rather focus on macro variables which are closely connected with defaults. Hence, we could predict the probable future trajectory of defaults in the Czech economy.

The following text starts with the main characteristics of the Czech economy introducing the historical evolution of the main macro series, continuing with a description of the data set and the model technique. The final part is devoted to empirical modelling and main findings.

\section{Main characteristics of the Czech economy}

The Czech economy has gone through a crucial period in the last few years; especially as the last economic crisis diffused through all the countries, we could see structural changes, strong contractions and high levels of unemployment. Figure 1 represents the quarterly development of the Czech GDP (nominal seasonally adjusted GDP) and unemployment from Q1-2000 to Q2-2012. A related development is shown in Figure 2, which plots loans and inflation and it can be seen that their progress is connected in time. 


\section{Figure 1}

\section{Development of GDP and unemployment}

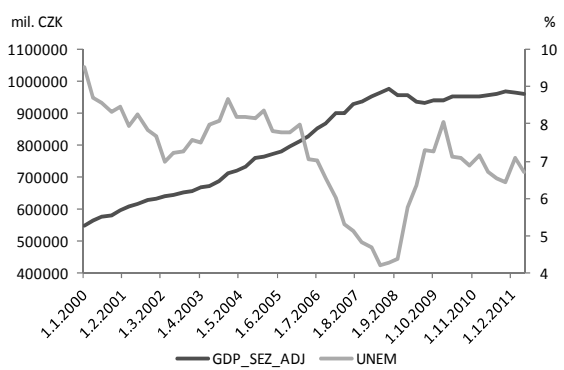

Source: Czech Statistical Office.

\section{Figure 2}

Development of loans and inflation

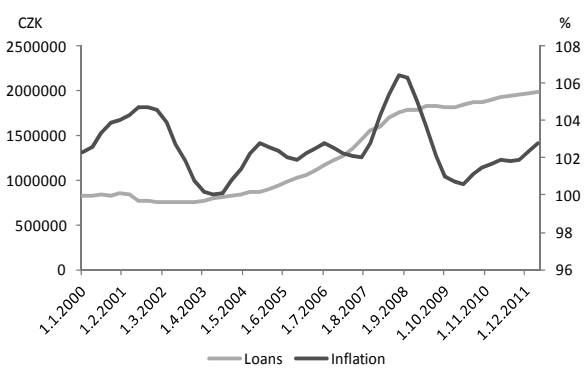

Source: Czech National Bank.

Since the paper is focused on defaults, important information is the development of corporate defaults in the Czech Republic's economy, which is shown in Figure 3 together with oil (Europe Brent Spot Price FOB). Similarly with the previous conclusion, we can see that there is a connection between these series; especially the last years of the crisis provide valuable information on the time series analysis - we can see what each series did when the external shock came. Finally, Figure 4 shows the development of the REPO2T and REER (Real Effective Exchange Rate) interest rates. A connection can be seen in this case also.

\section{Figure 3}

\section{Development of oil (Brent)} and corporate defaults

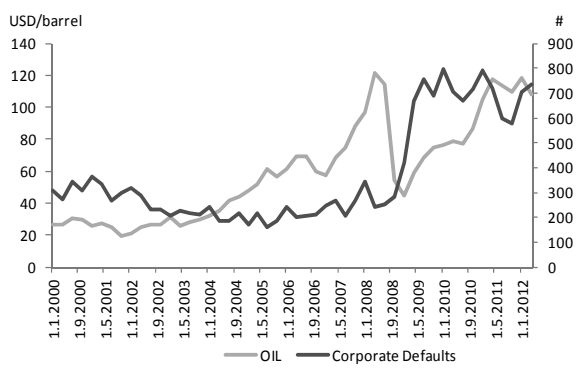

Source: Czech Statistical Office; Bisnode.

\section{Figure 4 \\ Development of REPO2T and REER}

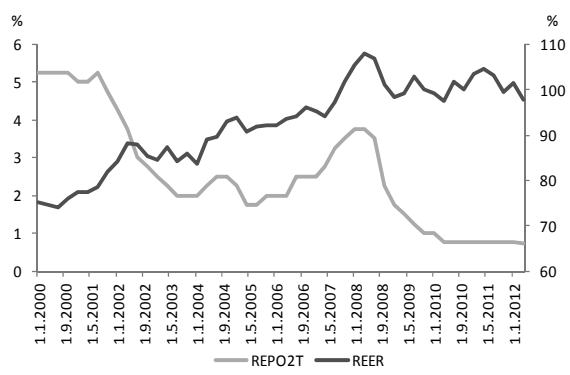

Source: Czech National Bank.

The convergence process for the Czech economy as one of the post-communist economies is typical: we can observe many interesting characteristics in the series. The Czech GDP has grown continuously but the unemployment has fluctuated around its mean of $7 \%$ with deviations, especially in the crisis period. The change of regime of the CNB to inflation targeting has brought many new opportunities for the economic agents. The disinflation process, which started after the CNB adopted this regime, was new for many subjects and monetary policy became one of the main tools for economic 
development. Thus, the REPO2T, as a main instrument of monetary policy, together with the REER, became more important for economic development. In the case of the defaults, we can observe that the number of defaults increased in the crisis period and then stabilised at a new level with almost the same variability before the external shock came. This specific behaviour is interesting for our analysis to reveal if there exists any connection which could explain this radical change.

We have seen that the main economic variables are connected and influencing each other. The key question is whether exists a relationship between them which can provide a stable macro model. If our answer will be positive, we can use VEC models to build a macro model.

\section{Data and model building details}

Data for corporate defaults in the Czech Republic were obtained from the company Bisnode, which is the main provider of high-value-added data and has available the largest database of economic entities with related information. Corporate defaults are registered in the Czech Commercial Register (CCR). Due to the connection between the CCR and Bisnode, together with corporate time series since the establishment of the Czech Republic, Bisnode has available a relevant data set for the purpose of this research: there are financial and economic data and date of default for each firm in the Czech Republic if it occurred. The rest of the data were obtained from the Czech Statistical Office and the Czech National Bank. We examined a few versions of seasonally adjusted nominal Czech GDP (CZK million), unemployment (\%), inflation (\%), monetary aggregate M2 (CZK million), REER (\%), oil (Europe Brent Spot Price FOB in dollars per barrel), Repo2T (\%) and loans (CZK million). We finally decided to use quarterly data at the original level. Each time series was used in the length from Q1-2000 to Q2-2012, thus we had 50 observations.

We used EViews 6.0 to build the models. In the first step, we examined correlations between variables and we also tested if there are any significant changes in various periods. This analysis proved that the full-length period has optimal characteristics without significant changes in correlations according to the length of the period. Then we tested the Granger causality with various lengths. This test proved that there are many simultaneous connections which should be modelled using the VAR or VEC system. The next step tested a unit root by the ADF and Phillips-Perron tests whereas we included intercept. These tests proved non-stationarity of all the time series. The lag length in the ADF test was set as an automatic selection on the basis of the SIC. First, differences in the variables proved stationarity for all the time series; thus, all of the time series are I(1). Then we tested cointegration using the Johansen Cointegration Test between all the variables and here we also tested whether the length of the period has a significant influence on the cointegration vector. We chose intercept in the CE and VAR, which is generally recommended by Johansen (1995) if the time series are I(1). We examined whether a cointegration vector exists between just two or more variables. Thus, we revealed the strongest connections between variables. Finally, we tested various lags depending on AIC, SC and HQ criteria.

After the tests outlined above, we started building a VEC model. We examined whether variables have significant coefficients and also whether they are explained 
endogenously regarding the whole system with the Granger causality/Block Exogeneity Wald test or rather exogenously. Variables with non-significant coefficients and without Granger causality to the defaults were eliminated. We also preferred the lag of the VEC system which represents the oil and GDP as exogenous regarding the whole system. Finally, we tested residuals of the system by using the autocorrelation LM test, a normality test using the square root of covariance (Urzua). A heteroskedasticity test was not possible due to insufficient number of observations.

\subsection{Model background}

The paper uses VEC models, so it is necessary to examine them closely. For the set of $n$ time series $y_{t}=\left(y_{1 t}, y_{2 t}, \ldots, y_{n t}\right)^{\prime}$ it is possible to express a VAR model of the order $p$ as $\operatorname{VAR}(p)$, thus

$$
y_{t}=A_{1} y_{t-1}+A_{2} y_{t-2}+\ldots+A_{p} y_{t-p}+u_{t}
$$

where

$\boldsymbol{A}_{\boldsymbol{i}}$ is a matrix of coefficients $n \times n$,

$u_{t}=\left(u_{1 t}, u_{2 t}, \ldots, u_{n t}\right)^{\prime}$ is an unobservable $i . i . d$. process.

Let us consider VAR(1) with two variables

$$
\begin{aligned}
& y_{t}=b_{10}-b_{12} z_{t}+c_{11} y_{t-1}+c_{12} z_{t-1}+\varepsilon_{y t}, \\
& z_{t}=b_{20}-b_{21} y_{t}+c_{21} y_{t-1}+c_{22} z_{t-1}+\varepsilon_{z t},
\end{aligned}
$$

with $\varepsilon_{i t} \sim$ i.i.d $\left(0, \sigma_{\varepsilon i}^{2}\right)$ and $\operatorname{cov}\left(\varepsilon_{y}, \varepsilon_{z}\right)=0$.

In the matrix form, we can express the structural form

$$
\left[\begin{array}{cc}
1 & b_{12} \\
b_{21} & 1
\end{array}\right]\left[\begin{array}{l}
y_{t} \\
z_{t}
\end{array}\right]=\left[\begin{array}{l}
b_{10} \\
b_{20}
\end{array}\right]+\left[\begin{array}{ll}
c_{11} & c_{12} \\
c_{21} & c_{22}
\end{array}\right]\left[\begin{array}{l}
y_{t-1} \\
z_{t-1}
\end{array}\right]+\left[\begin{array}{c}
\varepsilon_{y t} \\
\varepsilon_{z t}
\end{array}\right],
$$

or

$$
B X_{t}=\Gamma_{0}+\Gamma_{1} X_{t-1}+\varepsilon_{t} .
$$

To work with a VAR system, it is valuable to express it as a limitless reduced form as

$$
B^{-1} B X_{t}=B^{-1} \Gamma_{0}+B^{-1} \Gamma_{1} X_{t-1}+B^{-1} \varepsilon_{t},
$$

thus

$$
X_{t}=A_{0}+A_{1} X_{t-1}+e_{t}
$$

where

$$
\left[\begin{array}{l}
e_{1 t} \\
e_{2 t}
\end{array}\right]=\frac{1}{\left(1-b_{21} b_{12}\right)}\left[\begin{array}{cc}
1 & -b_{12} \\
-b_{21} & 1
\end{array}\right]\left[\begin{array}{l}
\varepsilon_{y t} \\
\varepsilon_{z t}
\end{array}\right] \text {, }
$$

where $\varepsilon$ is i.i.d., thus $e$ has the characteristics $\left(0, \sigma_{i}^{2}\right)$ and $E\left(e_{i t}\right)=0$. 
To work with a VEC system, it is possible to express it from (1) as:

$$
\Delta \mathrm{y}_{\mathrm{t}}=\Phi_{0}+\Gamma_{1} \Delta \mathrm{y}_{\mathrm{t}-1}+\cdots \Gamma_{\mathrm{p}-1} \Delta \mathrm{y}_{\mathrm{t}-\mathrm{p}+1}+\Pi \mathrm{y}_{\mathrm{t}-\mathrm{p}}+\varepsilon_{\mathrm{t}}
$$

where

$$
\Gamma_{\mathrm{i}}=-\mathrm{I}_{l}+\sum_{\mathrm{j}=1}^{\mathrm{i}} \Phi_{\mathrm{j}} \text { for } i=1, \ldots, p-1, \Pi=-\left(\mathrm{I}_{l}-\Phi_{1}-\cdots-\Phi_{\mathrm{p}}\right) .
$$

It can be seen that the VEC system in the form (2) contains the matrix П which incorporates long-term influences (3), which can be characterised as a common stochastic trend for connected variables, and the matrix $\Gamma_{\mathrm{i}}$ contains short-term effects, see Arlt and Arltová (2009), Johansen (1995), Kirchgassner, Walters (2007), Luetkepohl (2005), or Wooldridge (2003).

\section{Macroeconomic model}

The best model which passed all of the tests is shown below. Further analysis showed non-significant and redundant variables M2, REER, Inflation and REPO2T. With these variables, the models were less stable or showed explosive behaviour. On this basis, we decided for the final model with the variables Defaults, Loans, GDP, Unemployment and Oil. The model is able to explain more than $86 \%$ of the variance in the defaults and converge to a steady state relatively quickly. Statistics of unit roots are shown below in Table 1 .

\section{Table 1}

\section{Statistics of unit roots}

Null Hypothesis: DEFAULTS has a unit root

Exogenous: Constant

Lag Length: 0 (Automatic based on SIC, MAXLAG $=10$ )

\begin{tabular}{lccc}
\hline & & t-Statistic & Prob. $^{*}$ \\
\hline Augmented Dickey-Fuller test statistic & -0.467531 & 0.8886 \\
& & & \\
Test critical values: & $1 \%$ level & -3.571310 & \\
& $5 \%$ level & -2.922449 & \\
& $10 \%$ level & -2.599224 & \\
\hline
\end{tabular}

Null Hypothesis: LOANS has a unit root

Exogenous: Constant

Lag Length: 1 (Automatic based on SIC, MAXLAG=10)

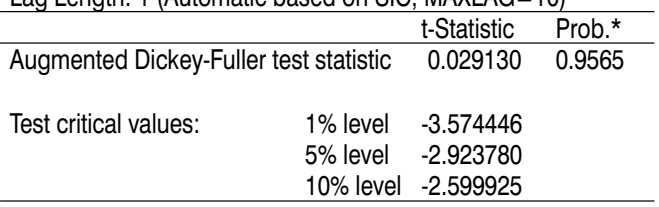

Null Hypothesis: UNEM has a unit root

Exogenous: Constant

Lag Length: 5 (Automatic based on SIC, MAXLAG =10)

\begin{tabular}{lccc}
\hline & t-Statistic & Prob. ${ }^{*}$ \\
\hline Augmented Dickey-Fuller test statistic & -1.889501 & 0.3341 \\
\hline Test critical values: & 1\% level & -3.588509 & \\
\hline & $5 \%$ level & -2.929734 & \\
\hline & $10 \%$ level & -2.603064 \\
\hline
\end{tabular}

\begin{tabular}{|c|c|c|c|}
\hline \multicolumn{4}{|c|}{$\begin{array}{l}\text { Null Hypothesis: GDP_SEZ_ADJ has a unit root } \\
\text { Exogenous: Constant } \\
\text { Lag Length: } 2 \text { (Automatic based on SIC, MAXLAG =10) }\end{array}$} \\
\hline & & t-Statistic & Prob.* \\
\hline $\begin{array}{l}\text { Augmented Dickey- } \\
\text { statistic }\end{array}$ & ller test & -1.542391 & 0.5037 \\
\hline Test critical values: & $\begin{array}{l}1 \% \text { level } \\
5 \% \text { level } \\
10 \% \text { level }\end{array}$ & $\begin{array}{l}-3.577723 \\
-2.925169 \\
-2.600658\end{array}$ & \\
\hline
\end{tabular}

Source: The author
Null Hypothesis: OIL has a unit root

Exogenous: Constant

Lag Length: 2 (Automatic based on SIC, MAXLAG=10)

\begin{tabular}{lccc}
\hline & & t-Statistic & Prob. $^{*}$ \\
\hline $\begin{array}{l}\text { Augmented Dickey-Fuller test } \\
\text { statistic }\end{array}$ & -0.803393 & 0.8089 \\
Test critical values: & $1 \%$ level & -3.577723 & \\
& $5 \%$ level & -2.925169 & \\
& $10 \%$ level & -2.600658 & \\
\hline
\end{tabular}


In the final model, we found 3 cointegration vectors and the same stochastic trend; Table 2 represents the Max-eigenvalue cointegration test.

Table 2

\section{Cointegration test}

\begin{tabular}{lclll}
\hline \multicolumn{4}{l}{ Unrestricted Cointegration Rank Test (Maximum Eigenvalue) } \\
\hline Hypothesised & Max-Eigen & 0.05 \\
No. of CE(s) & Eigenvalue & Statistic & Critical Value & Prob. ** $^{*}$ \\
None * & 0.793192 & 70.91839 & 33.87687 & 0.0000 \\
At most 1 * & 0.587317 & 39.82845 & 27.58434 & 0.0008 \\
At most 2 * & 0.471343 & 28.68367 & 21.13162 & 0.0036 \\
At most 3 & 0.214422 & 10.86011 & 14.26460 & 0.1613 \\
At most 4 * & 0.177394 & 8.787485 & 3.841466 & 0.0030 \\
\hline
\end{tabular}

Max-eigenvalue test indicates 3 cointegrating eqn(s) at the 0.05 level

* denotes rejection of the hypothesis at the 0.05 level

**MacKinnon-Haug-Michelis (1999) p-values

Source: The author

We used intercept in CE and VAR, which is generally recommended by Johansen (1995) if the time series are I(1); thus, we built our final VECM. Finally, it was not necessary to apply any restriction to the cointegration vectors, rather we composed cointegration vectors in a way which respects GDP and Oil as exogenous variables. Hence, we obtained the final vectors as shown in Table 3.

\section{Table 3}

\section{Cointegrations of the final model}

Standard errors in ( ) and t-statistics in [ ]

\begin{tabular}{|c|c|c|c|}
\hline Cointegrating Eq: & CointEq1 & CointEq2 & CointEq3 \\
\hline DEFAULTS(-1) & 1.000000 & 0.000000 & 0.000000 \\
\hline UNEM(-1) & 0.000000 & 1.000000 & 0.000000 \\
\hline LOANS(-1) & 0.000000 & 0.000000 & 1.000000 \\
\hline GDP_SEZ_ADJ(-1) & $\begin{array}{r}-0.005548 \\
(0.00089) \\
{[-6.21683]}\end{array}$ & $\begin{array}{c}4.18 \mathrm{E}-05 \\
(8.0 \mathrm{E}-06) \\
{[5.25339]}\end{array}$ & $\begin{array}{r}-9.370730 \\
(1.38022) \\
{[-6.78930]}\end{array}$ \\
\hline OIL(-1) & $\begin{array}{r}12.19564 \\
(4.48506) \\
{[2.71917]}\end{array}$ & $\begin{array}{r}-0.172646 \\
(0.03997) \\
{[-4.31922]}\end{array}$ & $\begin{array}{r}18610.78 \\
(6936.10) \\
{[2.68318]}\end{array}$ \\
\hline C & 3445.869 & -30.77790 & 5272312 . \\
\hline
\end{tabular}

Source: The author

After all the tests outlined, we obtained our final VECM model the quality and statistical accuracy of which is described in Table 4. 


\section{Table 4}

Main statistics of the final model

\begin{tabular}{lccccc}
\hline Statistics & DEFAULTS & UNEM & LOANS & GDP_SEZ_ADJ & OIL \\
\hline R-squared & 0.865116 & 0.862448 & 0.890117 & 0.706044 & 0.750037 \\
Adj. R-squared & 0.717387 & 0.711796 & 0.769769 & 0.384093 & 0.476267 \\
Sum sq. resids & 28391.33 & 1.396026 & $5.06 \mathrm{E}+09$ & $1.42 \mathrm{E}+09$ & 1561.703 \\
S.E. equation & 36.76912 & 0.257832 & 15515.23 & 8235.369 & 8.623620 \\
F-statistic & 5.856082 & 5.724773 & 7.396207 & 2.193014 & 2.739665 \\
Log likelihood & -208.9137 & 14.29100 & -480.9351 & -452.4328 & -143.6568 \\
Akaike AIC & 10.35172 & 0.431511 & 22.44156 & 21.17479 & 7.451414 \\
Schwarz SC & 11.31527 & 1.395064 & 23.40511 & 22.13834 & 8.414967 \\
Mean dependent & 8.222222 & -0.039310 & 25386.87 & 8116.600 & 1.834296 \\
S.D. dependent & 69.16511 & 0.480272 & 32335.28 & 10493.62 & 11.91612 \\
\hline \multicolumn{7}{c}{ Determinant resid covariance (dof adj.) } & $3.90 \mathrm{E}+19$ & & & \\
Determinant resid covariance & $8.64 \mathrm{E}+17$ & & & \\
Log likelihood & -1248.514 & & & \\
Akaike information criterion & 61.48952 & & & \\
Schwarz criterion & 66.90950 & & &
\end{tabular}

Source: The author

When we look at Table 3, we can see that the first cointegrating vector, the long-term equilibrium, is between the defaults, GDP and oil. We can see that an increase in the GDP causes an increase in the defaults (in a cointegration vector in the VECM model, a negative sign means a positive influence, and vice versa). This might seem as a contradiction to the expected effect. On the other hand, the level of the GDP continuously grew from Q1-2000 to the beginning of the economic crisis Q1-2009; the defaults also increased in this period. This fact should be connected with the economic development in the Czech Republic - a greater number of businesses -, as in many post-communist economies and with cheaper and more available money. As new businesses were established and the economy grew, more defaults occurred as a result of non-fundamental businesses in a developing economy. In other words, entrepreneurs tried new businesses in new fields without relevant knowledge, thus sooner or later they had to default; the more businesses the more defaults in an absolute value. Hence, the convergence process in the Czech Republic causes higher GDP and higher number of defaults. Furthermore, an increase in oil influences the defaults in a negative way in the long term; hence, the higher price of oil, the lower the level of the defaults. Generally, a higher price of oil leads to higher prices of inputs for producers, thus they can be more prone to default. However, higher prices of oil are usually connected with lower performance of economies in the long term. With the previous result for the GDP and the defaults under the Czech conditions, we can conclude that higher prices of oil in general mean lower performance of the economy, hence a lower level of defaults.

The second cointegration vector connects the unemployment, GDP and oil. In the first case, we can observe that the higher the GDP, the lower the unemployment, which is a generally accepted result. In general, we can observe this substitute effect in many developed economies; on the other hand, it does not mean necessarily that we will 
observe this connection in all the sectors of the Czech economy; rather, it is possible to find a positive connection between the unemployment and the GDP in a particular branch where there is growing productivity and effectiveness as a result of the convergence process. The second connection, between the unemployment and oil, implies a higher level of unemployment if oil increases. This conclusion is similar with the case of defaults, thus we consider a contraction on the production side; hence, higher unemployment occurs when the performance of the economy goes down.

The last long-term equilibrium, between loans, GDP and oil, reveals that higher GDP increases the amount of loans. We assume that the economy needs more loans when growing and going through the convergence process, which is the general behaviour of developed economies. Oil implies a lower level of loans, which leads us to conclude that in general loans reflect performance of an economy; thus, our conclusion in the case of defaults and unemployment are confirmed even in the case of loans.

We have examined the long-term equilibriums connected with the defaults and other variables. For reactions in the defaults as a response to a change in a different variable, we can use the commonly known Impulse-Response (IR) function, shown in Figure 5. IR functions are also a good instrument to reveal total reaction of the defaults from the short and long-term aspect. Since our software charts are without units, we repeat that the defaults are the number of firms which defaulted in a particular quarter, the GDP (CZK million), the unemployment (\%), the inflation (\%), the oil (dollars per barrel), the loans (CZK million). Each chart has the time period in quarters by the horizontal line and the unit of the particular variable by the vertical line.

\section{Figure 5}

\section{Impulse response function of the defaults}

Res ponse to CholeskyOne S.D. Innovations

Response of DEFAULTS to DEFAULTS

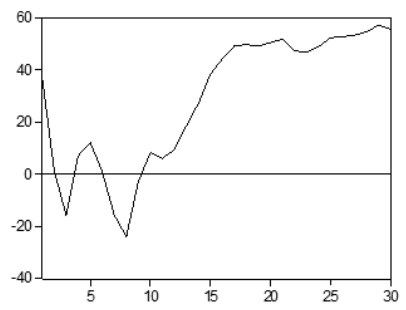

Response of DEFAULTS to LOANS

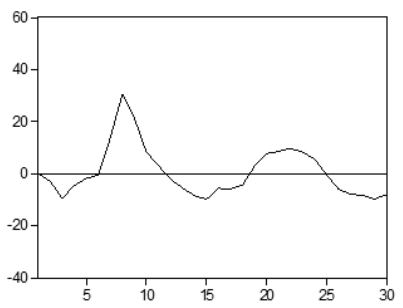

Response of DEFAULTS to UNEM

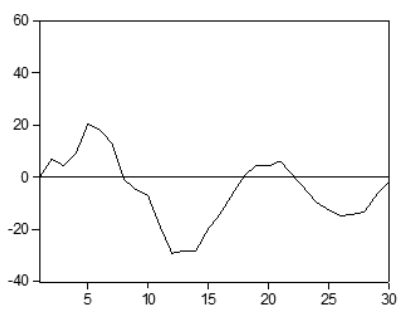

Response of DEFAULTS to GDP_SEZ_ADJ

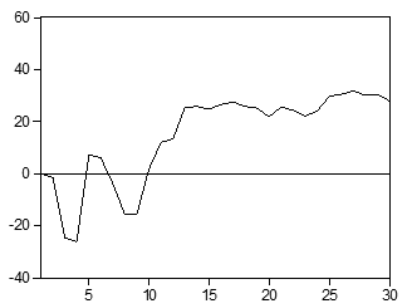

Response of DEFAULTS to OIL
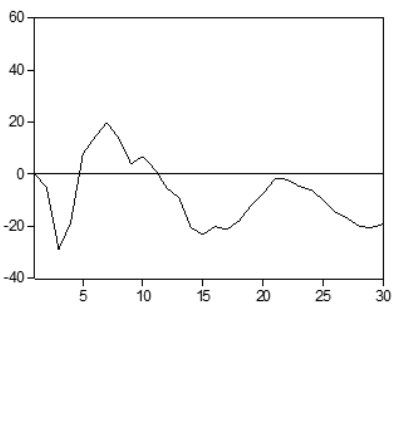

.


In the short term, we can see that the GDP causes the strongest reaction of the defaults, which increase to a new level. This result is very interesting: at the very beginning, the number of defaults decreases as the economy goes up, but after a few periods the number of defaults increases as a consequence of the convergence process. The rest of the variables has lower power, as in all the cases the defaults go back to the steady state relatively quickly. If we look at Figure 6, our findings reveal a strong and negative (increase) evolution of the defaults in the long term as a reaction to the changes in the GDP. This conclusion confirms our findings and makes us realise the characteristics of the Czech economy. As has been mentioned before, when an economy grows, the GDP grows; at the very beginning of this process, we can observe decreases in the number of defaults, but later, when competition among firms is higher and overheating of the economy is probable, many new businesses without a strong economic fundament default. Thus, we can observe a higher level of defaults as these new businesses go bankrupt. On the other hand, oil and loans have the opposite effect on the defaults. In the case of oil, we assume that higher prices of inputs and probable economic contraction together with a probable increase in inflation can lead to cheaper loans or loan repayment of debtors and, finally, new businesses are not being founded in these times at same rate as in conjunction, thus the number of defaults decreases.

\section{Figure 6}

\section{Accumulated impulse response function of the defaults}

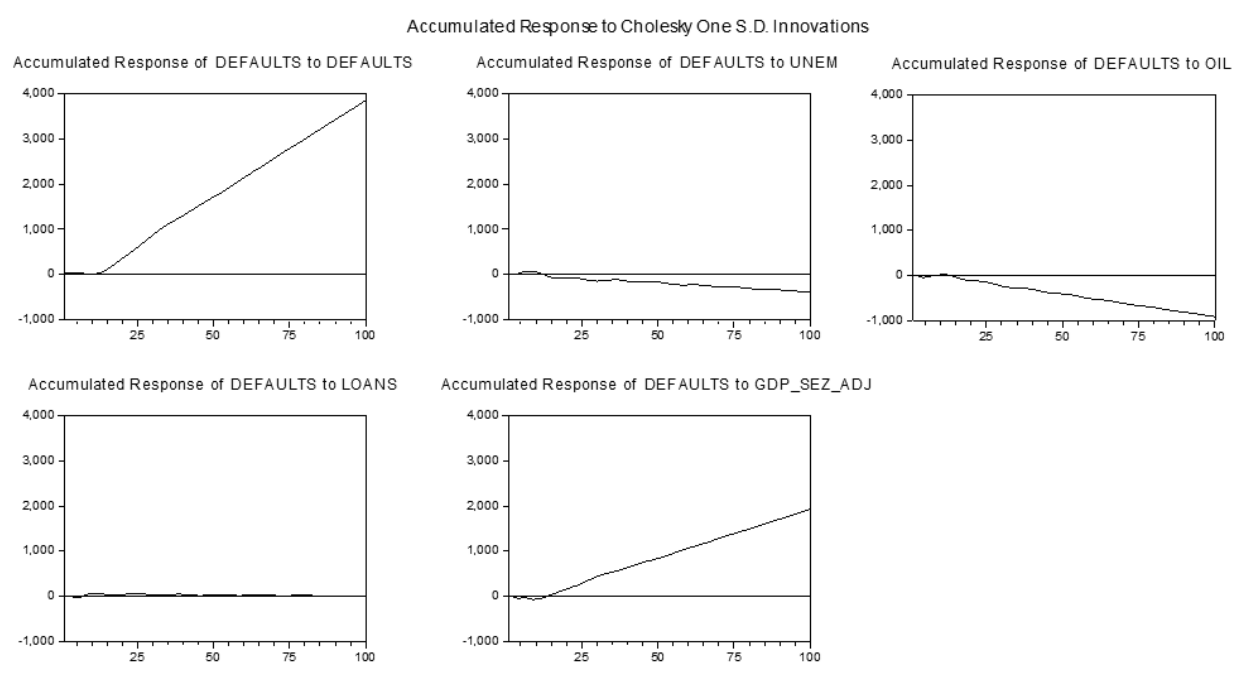

Source: The author

In the sense of total impact on the defaults, we can observe that the GDP has the strongest effect compared with the rest of the variables. This fact comes from the cointegration connections. Figure 7 shows the cointegration relations. 


\section{Figure 7}

\section{Cointegration relations}
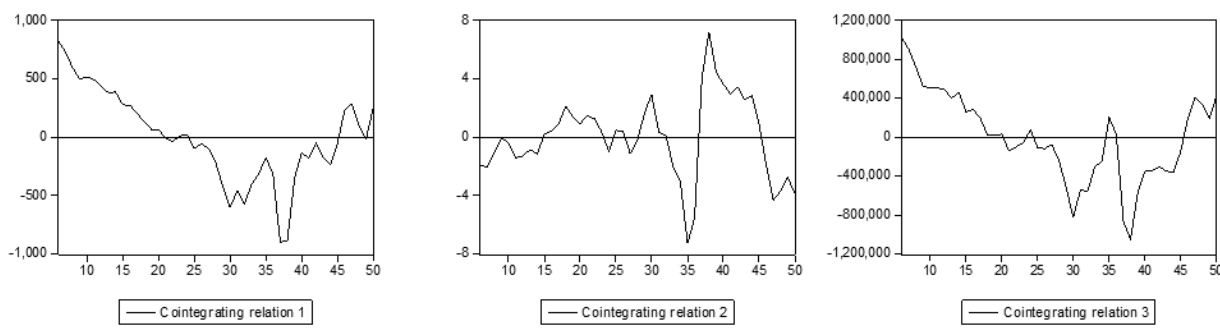

Source: The author

We can observe significant changes mainly in the crisis period, which means that each time series has its own characteristics which are not integrated into the rest of the connected series, thus the fluctuations are stronger under extreme conditions.

To assure quality and robustness of our model, it is necessary to estimate an ex-post prediction. Figure 8 shows the ex-post prediction of our model and it can be seen that the model fits empirical data very well; in other words, we can observe a good connection with the empirical data and the standard deviations are relatively small. Hence, the model can be considered reliable to induce the conclusions mentioned above.

\section{Figure 8}

\section{Ex-post prediction}

DEFAULTS

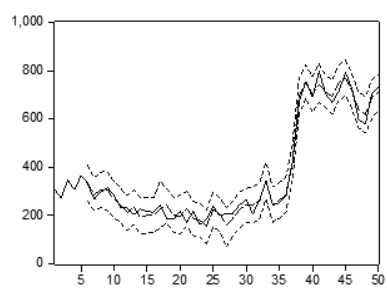

- Actual --DEFAULTS (Baseline Mean)

LOANS

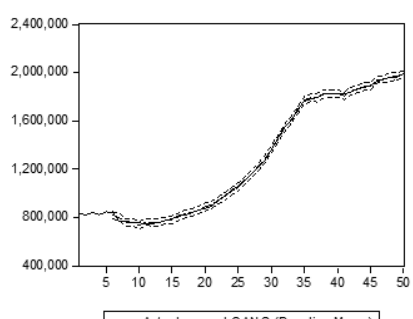

-Actual -- LOANS (Baseline M ean)
GDP_SEZ_ADJ

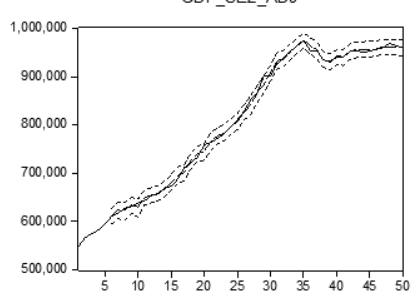

- Adual

$\mathrm{OlL}$

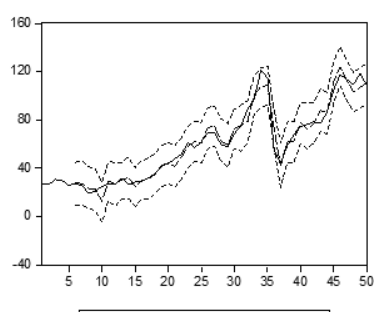

UNEM

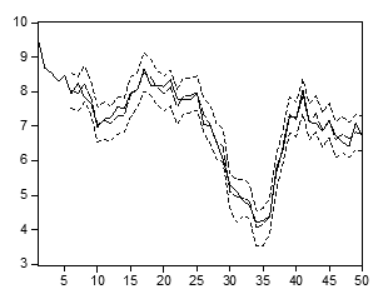

- Actual -- UNEM (Baseline M ean)

Source: The author 
Finally, Figure 9 explicitly shows the quality of the model. The ex-ante predicted trajectory for all of the variables follows the empirical data even though the model predicts data from the very beginning, which confirms the quality of the model. Thus, the model can be used for the prediction of the defaults for the next period 2013.

\section{Figure 9}

\section{Ex-ante prediction}
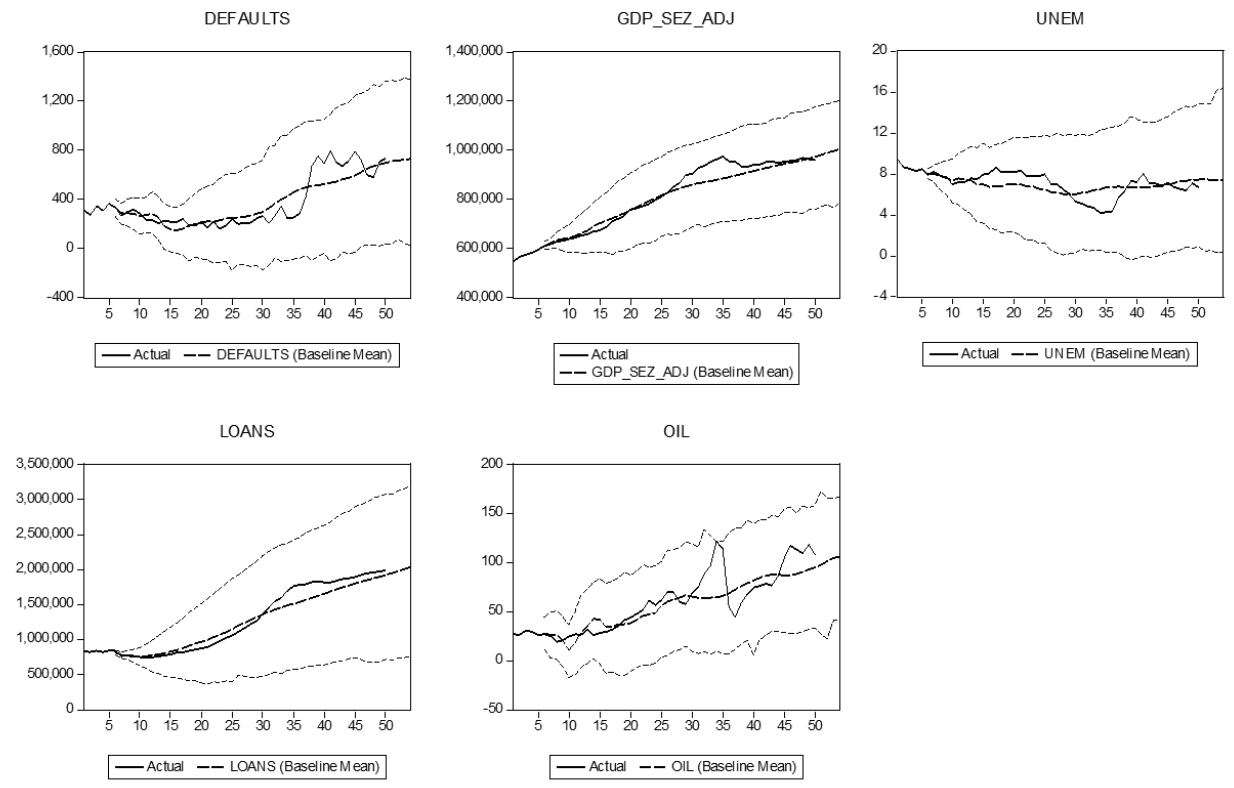

Source: The author

Using an ex-ante (dynamic) prediction from 2012Q3 to 2013Q3, we obtained predictions for all of the variables. The prediction for the defaults revealed a worse situation in 2013 than in 2012: the number of defaults will grow with a high probability. This conclusion is coherent with all of the results which have been obtained in the article.

\section{Conclusion}

The paper constitutes a formal econometric assessment of the main macroeconomic fundaments connected with firms' defaults. We analysed the Czech GDP, loans, unemployment and prices of oil (Brent) together with corporate defaults, the number obtained from the database of Bisnode.

In our research, we tested many variants of possible connections among the examined variables. The final model conformed to all of our requirements and was the most stable of all. 
The model revealed that in the long term, the GDP has a negative (increasing) effect on the defaults. Our conclusions revealed consequences of the convergence process of the Czech Republic for the number of defaults. Hence, when the economy grows, the GDP grows; at the very beginning of the process, we observe a decreasing number of defaults, but later comes a redefinition of the new development of the economy, and competition among firms also grows. Thus, many new businesses without a strong economic fundament go into default in this situation. Hence, we can observe a higher rate of defaults as these new businesses go bankrupt in the growing and developing economy. In other words, the more businesses the more defaults in an absolute value. Hence, the convergence process in the Czech Republic causes a higher GDP together with a higher number of defaults.

The next significant variable in the long-term period was the price of oil (Brent). Generally, if the price of oil increases, we can expect higher prices of inputs and an economic contraction. Furthermore, we can expect an increase in inflation. These facts together lead to cheaper loans or cheaper loan repayment for debtors. This effect is also connect to the fact that a lower rate of new businesses can be seen in such times as a result of an economic contraction. Thus, a lower level of defaults can be expected.

We proved a general connection between corporate defaults and the macroeconomic condition of the economy, influenced by the convergence process. Our specific findings are new and have not been observed yet; we would say that we were able to reveal new findings due to the large database that was provided for this purpose.

Our findings showed that a worse condition of the Czech economy can be expected in 2013, which will be reflected in the numbers of defaults. Hence, the number of defaults will probably grow.

\section{References}

ARLT, J.; ARLTOVÁ, M. Ekonomické časové řady. Př́bram : Kamil Mařík - Professional Publishing, 2009. ISBN 978-80-86946-85-6.

BANGIA, A.; DIEBOLD, F.; KRONIMUS, A.; SCHAGEN, C.; SCHUERMANN, T. Ratings migration and the business cycle, with application to credit portfolio stress testing. Journal of Banking and Finance. 2002, vol. 26, no. 2 \& 3, pp. 445-474.

JOHANSEN, S. Likelihood-Based Inference in Cointegrated Vector Auto-regressive Models. New York : Oxford University Press, 1995. ISBN 0-19-877450-8.

KAVVATHAS, D. Estimating credit rating transition probabilities for corporate bonds. AFA New Orleans Meetings, 2001. Available at SSRN: http://papers.ssrn.com/sol3/papers.cfm?abstract_ $\mathrm{id}=252517$.

KIRCHGASSNER, G.; WOLTERS, J. Introduction to Modern Time Series Analysis. Berlin : Springer, 2007. ISBN 978-3-540-68735-1.

LUETKEPOHL, H. New Introduction to Multiple Time Series Analysis. Berlin : Springer, 2005. ISBN $978-$ 3-540-40172-8.

MILLER, D.; FRIESEN, P. H. A Longitudinal Study of the Corporate Life Cycle. Management Science. 1984, vol. 30, no. 10, pp. 1161-1183.

NICKELL, P.; PERRAUDIN, W.; VAROTTO, S. Stability of rating transitions. Journal of Banking and Finance. 2000 , vol. 24, no. $1 \& 2$, pp. 203-227. 
PESARAN, M. H.; SCHUERMANN, T.; TREUTLER, B.-J.; WEINER, S. M. Macroeconomic dynamics and credit risk: a global perspective. CESifo Working Paper Series. 2003, no. 995. Available at SSRN: http://papers.ssrn.com/sol3/papers.cfm?abstract_id $=432903$.

WILSON, T. Portfolio credit risk. Economic Policy Review. 1998, vol. 4, no. 3, Available at SSRN: http:// ssrn.com/abstract $=1028756$.

WOOLDRIDGE, M. J. Introductory Econometrics: A Modern Approach. USA : South-Western College Pub, 2003. ISBN 978-0-324-11364-8.

\title{
MACROECONOMIC MODELLING OF A FIRM'S DEFAULT
}

\begin{abstract}
Enormous development of firm valuation from many aspects can be seen in the recent period. One of the main fields is scoring, which provides a probability verdict about the future development of a firm: its probability of default. This article focuses on introducing macroeconomic modelling using VEC models to predict the future level of default in the Czech economy. Our results have proven a general connection between corporate defaults and the macroeconomic condition of the economy, which is going through a convergence process. The specific findings are new and have not been observed yet. A connection between the GDP and defaults revealed a positive relationship, which is probably a consequence of the convergence process, a development of the economy in many new fields. We have also found a long-term equilibrium among unemployment, loans, price of oil and defaults. We have revealed a higher level of defaults can be expected in 2013 , which is connected with the economic contraction in the prediction period.
\end{abstract}

Keywords: scoring, econometric modelling, VEC, corporate default

JEL Classification: C32, C53, E17

HEŘMAN, J.; HOROVÁ, O. Průmyslové technologie pro ekonomy. 1. vyd. Praha : Vysoká škola ekonomická, Nakladatelství Oeconomica, 2013. 1. vyd. 260 s. ISBN 978-80-245-1907-4.

Učebnice je určena k získání, popřípadě rozšiřrení znalostí zejména v oblastech výrobní techniky a vybraných, nejčastěji používaných technologií, s nimiž se mohou absolventi ekonomických univerzit setkat po nástupu do průmyslových podniků. Obsah publikace je zaměřen na problematiku základních výrobních prostředků, produkčních principů a technologických postupů, poskytuje čtenářum pohled na fungování vybraných oblastí výrobního procesu firmy a ukazuje na provázanost poznatků s dalšími teoretickými disciplínami, jako jsou ekonomika podniku, podnikový management, logistika, finanční řízení firmy a další. 